\title{
Status of Traditional Beekeeping and Various Threats to Bees in Climate Changing Scenario in District Ganderbal of Kashmir
}

\author{
Muneer Ahmad*, A.A. Khan and Nadeem Dar \\ Division of Entomology, Sher-e-Kashmir University of Agricultural Sciences and Technology \\ Shalimar Srinagar, Kashmir, J\&K, India \\ *Corresponding author
}

\begin{abstract}
A B S T R A C T
\end{abstract}
Survey was undertaken to assess honey production system, identify major beekeeping constraints and determine the association of potential risk factors with occurrence of

\section{Keywords}

Traditional beekeeping, Threat, Climate change, Kashmir

Article Info

Accepted:

04 April 2019

Available Online:

10 May 2019 honeybee diseases, predators and pests at Ganderbal district of Kashmir during summer 2018. Questionnaire survey and laboratory diagnostic methods were employed. A total of 50 beekeepers were included in the questionnaire survey and were interviewed through questionnaire survey, $64.5 \%$ had knowledge about honey bee diseases and pests. A total of 384 honey bee colonies were randomly examined for the presence of honeybee external parasites and pathogenic diseases. Regarding honeybee pests and predators, the rank index confirmed that the most important pests and predators affecting Traditional honeybee colonies were wax moth (18.2\%), Bee lice (12.3\%), hive Beetles (7.2\%), and bee eater birds $(7 \%)$. The major constraints affecting beekeeping development in the study areas in decreasing order were pests and predators (17.5\%), high cost of modern hives and accessories (15.5\%), agro-chemical application (14.3\%), honey bee diseases $(11.9 \%)$, poor management $(10.5 \%)$, winter mortality of honeybee colony $(10.5 \%)$, shortage of bee forage $(10.2 \%)$ and absconding $(9.6 \%)$. The study demonstrated that honey productions in the study area are hampered by several constraints and pests. Therefore, improvement of honey bee hive management, disease and pests prevention are paramount important.

\section{Introduction}

Kashmir is home of diverse flora which is used by bees as their source of pollen and nectar. Its forests and different agroecosystem, apple orchards and forests contain diverse plant species that provide surplus nectar and pollen to foraging bees. The state is the major honey producer in India. Although thousands of tones of honey have been produced every year, the products obtained from the subsector have been observed to still low as compared to the potential of the state.

In district Ganderbal, Kashmir, Bee keeping is a promising non-farm activity for the rural households. It contributes to the incomes of households in particular and the economy of the state in general. It also provides an employment opportunity in the livestock sub sector of the agriculture and horticulture 
sector. The exact number of people in Ganderbal is not well known. However it was also observed large number of people (intermediaries and traders) participate in honey collection and retailing at village level and district level). Beekeeping is a very longstanding practice in the farming communities of the Ganderbal and it plays a significant role as source of additional cash income and nutrition for many subsistence farmers.

It is an integral part of the smallholder farming system. Despite the significance of bee keeping, there is little empirical evidence on the potentials and challenges of bee keeping for income generation in the study districts.

There is limited information currently available on the constraints of bee keeping in the honey bee sub-sector. The objective of the study, therefore, was to analyze the major honey bee production opportunities and challenges in the bandipora district of Kashmir.

\section{Materials and Methods}

\section{Study area}

The study was conducted in district ganderbal of Kashmir. The latitude is 34.42 Longitude 74.66.

\section{Sample size and sampling technique}

Total of 50 bee-keepers were selected.

Data type, source and data collection techniques

The study is relied on primary data collected from household heads, beekeepers. The survey methods have been used to collect the required data questionnaire was used to collect the required primary data.

\section{Data analysis}

The data collected from 50 bee-keepers were analysed and is rank indexed to put the order of importance of pests and predators, which are challenges for honey bee production in the study area

Rank index was calculated as follows

Rank Index $=$ Sum of $\left(3^{*}\right.$ number of household ranked first $+2 *$ Number of household ranked second+ $1^{*}$ number of household ranked third) for individual reason divided by sum of $\left(3^{*}\right.$ number of household ranked first $+2 *$ number of household ranked second $+1^{*}$ number of households ranked third) for over all reason.

\section{Results and Discussion}

Based on the survey data analysis most of the beekeepers in the study area of Ganderbal reported to have faced different challenges in relation to beekeeping (Table 1). The survey predicts that on an average $(90 \%)$ of the beekeepers reported different challenges in beekeeping. Though the challenges reported indicated variation across the study districts financial problems, pests and high input cost, poor extension services, pests and predators, high input costs are the most economically important challenges in the area. The households also listed (17.5\%) major pests and predators observed in the study area at their rank-first (Table 2). Accessories (15.5\%) were one of the pressing factors that affect the beekeeping activity of the study district. Depending on the survey data most of the farmers of the study district reported that agrochemical is one of the challenge $(14.3 \%)$ in the beekeeping upliftment. The data predicted $11.9 \%$ respondents reported honey bee diseases as the threat .Poor management, winter mortality, Bee forage and absconding reported by $10.5,10.5,10.2$ and $9.6 \%$ 
respondents respectively of the challenges of beekeeping sector in the study area.

Different pests and predators which include wax moth, hive bee lice, hive beetle, bee eater bird and wasp are listed in table 2 as per their rank. Wax moth was among most common predators of honeybees in the area with rank first. Based on the beekeepers response wasp was put in the second rank in the study area. Bee eater bird ranked third in the response whereas Hive scorpion and hive beetles ranked fourth in the response of the study area (Fig. 1-3).

Table.1 Response proportions of major challenges of bee-keeping in district Ganderbal

\begin{tabular}{|l|c|c|}
\hline List of honey production factors & Status (\%) & Rank \\
\hline Predators & 17.5 & 1 \\
\hline Bee equipment non availability & 15.5 & 2 \\
\hline Agro-chemicals & 14.3 & 3 \\
\hline Honey bee diseases & 11.9 & 4 \\
\hline Poor management & 10.6 & 5 \\
\hline Winter mortality & 10.4 & 6 \\
\hline Shortage of bee forage & 5.0 & 9 \\
\hline Absconding & 9.6 & 7 \\
\hline Poor extension services & 5.5 & 8 \\
\hline
\end{tabular}

Table.2 Rank index for major pests and predators of bee keeping in district Ganderbal

\begin{tabular}{|l|l|c|c|}
\hline S.No & Name of pests and predators & $\begin{array}{c}\text { Percentage } \\
(\mathbf{\%})\end{array}$ & Rank \\
\hline $\mathbf{1}$ & Wax moth(Achroia grisella) & 38.0 & 1 \\
\hline $\mathbf{2}$ & Bee-louse (Braula coeca) & 11.9 & 5 \\
\hline $\mathbf{3}$ & Hive beetles (Aethina tumida) & 12.0 & 4 \\
\hline $\mathbf{4}$ & Bee eater Bird & 13.1 & 3 \\
\hline $\mathbf{5}$ & Wasp (vespa orientalis) & 25.0 & 2 \\
\hline
\end{tabular}

Fig.1 Various threats of Apis cerana Colonies in Ganderbal

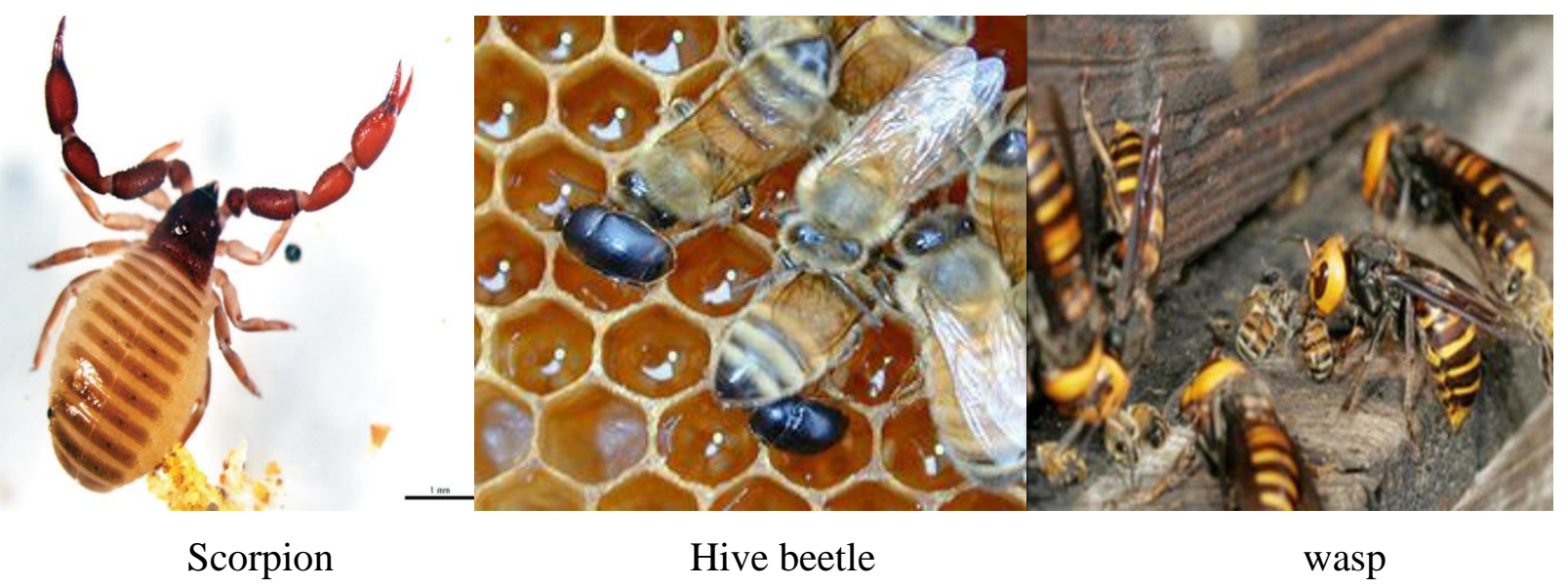


Fig.2 The threats of Apis cerana in Kashmir valley

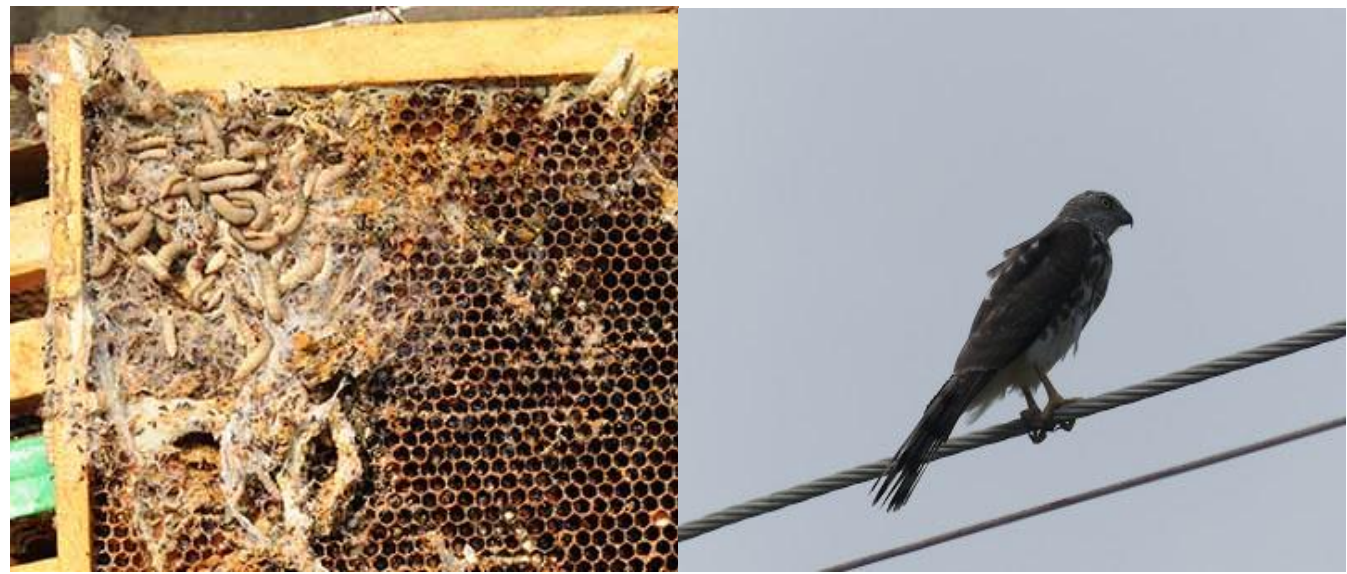

Wax moth

Bee eater

Fig.3 The traditional pattern of honey bee Apis cerana in Kashmir valley

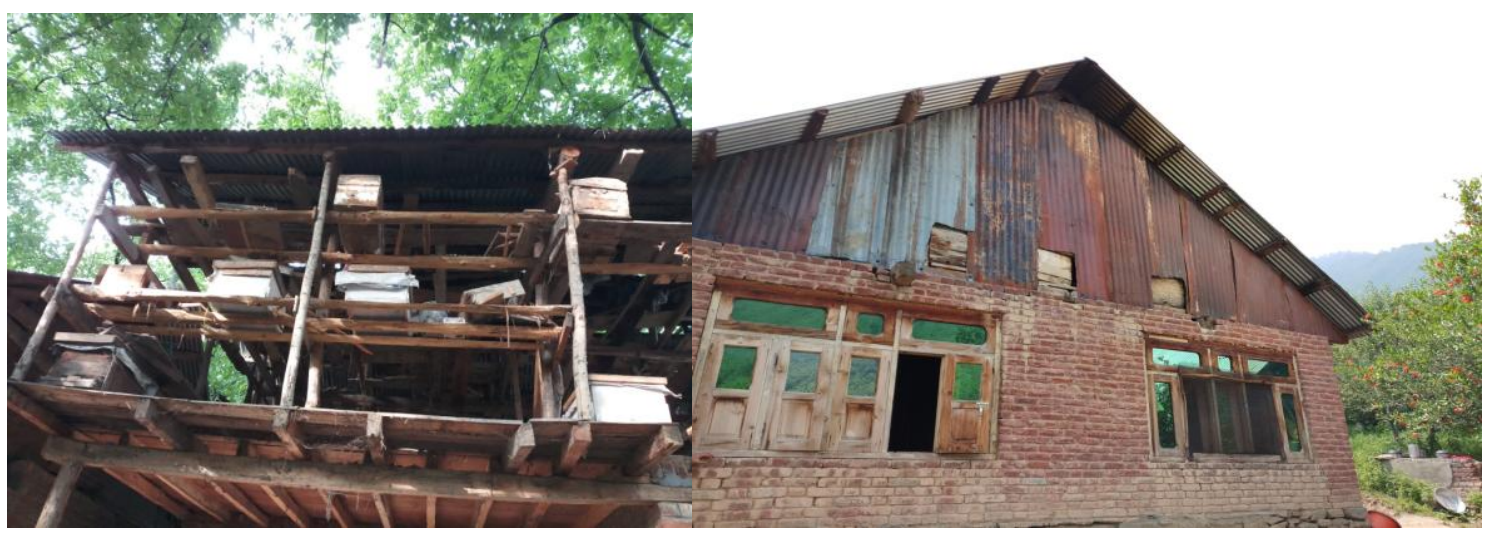

\section{Conclusion and recommendations}

The Ganderbal district of Kashmir valley has tremendous scope for beekeeping and ample amount of bee forage is available from March to October. Apiculture has huge potential in the area as bees are vital pollinators of major fruit apple in the district on which major chunk of the population livelihood is dependent there are major constraints of beekeeping in the area like pests and predators. Secondly the non availability of minor equipments required is also a hindrance. The administrative bodies and agriculture department has to strive more towards improving the quality and adequacy of extension services in relation to beekeeping in the study district. Production, productivity and quality of honey shall be also increased by improving the management of the traditional beehives and introduce improved beehives or local lopun system in the area. The supplementary feeding in the form of sugar during dearth period can stop the bee absconding. Proper winter management to bee colonies will reduce the winter mortality upto great extent.

\section{Acknowledgement}

The present work has been carried under DST funded project. We are very thankful to the funding agency for financial support. 


\section{References}

Antu'nez, K., Invernizzi, C., Mendoza, Y., vanEngelsdorp, D., and Zunino, P. (2017). Honey bee colony losses in Uruguay during 2013-2014. Apidologie, 48, 364-370. doi:10.1007/ s13592-016-0482-2

Berthoud, H., Imdorf, A., Haueter, M., Radloff, S., and Neumann, P. (2010). Virus infections and winter losses of honey bee colonies (Apis mellifera). Journal of Apicultural Research, 49, 60-65. doi:10.3896/IBRA.1.49.1.08

Borneck, R., and Merle, B. (1989). Trial to evaluate the economic incidence of the pollinating honey bee in the European agriculture. Apiacta. Brodschneider, R., and Crailsheim, K. (2010). Nutrition and health in honey bees. Apidologie, 41, 278-294.

Çakmak I., Aydin L, Seven S and Korkut M (2003). Beekeeping Survey in Southern Marmara Region of Turkey. Uludag Bee Journal, 3(1): 31-36.

Charrière JD, and Neumann P (2010). Surveys to estimate winter losses in Switzerland. Journal of Apicultural Research, 49(1): 132- 133.

Curri,e RW. Pernal SF and Guzmán-Novoa E (2010). Honey bee colony losses in Canada. Journal of Apicultural Research, 49(1): 104-106.

Dahle, B., (2010). The role of Varroa destructor for honey bee colony losses in Norway. Journal of Apicultural Research, 49(1): 124-125.

Ellis, JD., Evans JD and Pettis J (2010). Colony losses, managed colony population decline, and Colony Collapse Disorder in the United States. Journal of Apicultural Research, 49(1): 134-136.

Gajger, IT., Tomljanovic, Z., and Petrinec Z (2010). Monitoring health status of
Croatian honey bee colonies and possible reasons for winter losses. Journal of Apicultural Research, 49(1): 107-108.

Gallai N., Salles JM, Settele J and Vaissière BE, (2009). Economic valuation of the vulnerability of world agriculture confronted with pollinator decline, Ecological Economics, 68: 810-821.

Harris, J.L., 1980. A population model and its application to the study of honey bee colonies. MSc Thesis, University of Manitoba, 104 pp.

Huang, Z.Y., and G.E. Robinson, 1992. Honeybee colony integration worker-worker interactions mediate hormonally regulated plasticityin division of labour. Proc. Natl. Acad. Sci. USA. 89: 11726-11729.

Huang, Z.Y., and G.E. Robinson, 1995. Seasonal changes in juvenile hormone titres and rates of biosynthesis in honey bees. J. Comp. Physiol. B 165: 18-28.

Jaycox, E.R., 1976. Behavioral changes in worker honey bees (Apis mellifera) after injection with synthetic juvenile hormone (Hymenoptera: Apidae). J. Kans. Entomol. Soc. 49: 165-170.

Kefuss, J.A., 1978. Influence of photoperiod on the behaviour and brood-rearing activities of honeybees in a flight room. J. Apic. Res. 17: 137-151.

Kunert, K. and K. Crailsheim, 1988. Seasonal changes in carbohydrate, lipid and protein content in emerging worker honeybees and their mortality. J. Apic. Res. 27: 13-21.

Maurizio, A., 1950. The influence of pollen feeding and brood rearing on the length of life and physiological condition of the honeybee. Bee World 31: 9-12.

Neukirch, A., 1982. Dependence of the life span of the honeybee (Apis mellifica) upon flight performance and energy consumption. $J$. Comp. Physiol. 146: 35-40.

\section{How to cite this article:}

Muneer Ahmad, A.A. Khan and Nadeem Dar. 2019. Status of Traditional Beekeeping and Various Threats to Bees in Climate Changing Scenario in District Ganderbal of Kashmir. Int.J.Curr.Microbiol.App.Sci. 8(05): 372-376. doi: https://doi.org/10.20546/ijcmas.2019.805.043 